\title{
EASTERN RANGE EXTENSION OF THE SAY'S PHOEBE INTO SOUTH-CENTRAL MANITOBA
}

KEN D. DESMET, Box 184, Group 550, R.R. 5, Winnipeg, Manitoba. R2C $2 Z 2$

The breeding range of the Say's Phoebe formerly extended into southwestern Manitoba to Oak Lake and Aweme. ${ }^{2} 45$ The only recent nesting records for Manitoba, however, are in the extreme southwestern corner of the province near Lyleton. In this area, Knapton reported up to two pairs of Say's Phoebes nesting from 1972-1977.2 3 Recently, three to four breeding pairs per year have been located in Lyleton and in abandoned farmhouses south and west of town (J.L. Murray, pers. comm.). This article reports on several recent sightings and a nest record of the Say's Phoebe 100 to $150 \mathrm{~km}$ east of Lyleton in south-central Manitoba.

While conducting the Mather Breeding Bird Survey on 15 June 1985, Wayne NeiIy and I heard an unfamiliar phoebe-like call at an abandoned farmyard $7 \mathrm{~km}$ southsouthwest of Mather. Although it was dark and foggy, we managed to locate the bird, a Say's Phoebe, on a nearby fence post. After completing the survey we searched the abandoned farmhouse and a nearby grainery, but no nest was located. We did, however, briefly observe two adult Say's Phoebes. These birds were subsequently observed by several other Rare Bird Albert members in Manitoba, but neither a nest or immatures were found.

Although Knapton reported the average arrival date for southwestern Manitoba as 30 April, there were no Say's Phoebes at the Mather site on 23 May $1986 .{ }^{3}$ On 26 and 27 June, however, Ted Grewe and I recorded two adults at this site during the Mather Breeding Bird Survey. Once again, a thorough search of the house and grainery produced no nesting evidence. After getting rained out of the original survey on 26 June, we stopped at another abandoned house $12 \mathrm{~km}$ southeast of Killarney. To our amazement, a pair of Say's Phoebes were there as well! This time a nest was located in a horizontal section of stove pipe. The nest contained five almost fully-feathered young. A similarlooking nest was located in a chimney ledge on the upper floor suggesting that Say's Phoebes may also have been present at this site the year before. The excited behavior of both adults differed from the unconcered manner of the Mather pair. Hence, it was suspected that the former pair may not yet have been nesting. When I revisited the Mather site on 23 July, no Say's Phoebes were observed.

On 23 July 1986, Cal Cuthbert (pers. comm.) collected additional evidence of nesting 35 kilometers east of the Mather site. On that date he observed one adult and two immatures along a fenceline $8 \mathrm{~km}$ north of Snowflake. The young were observed feeding themselves, but they occasionally begged for food from the adult. A nearby abandoned farmstead was believed to have been where this family had been raised.

These observations suggest that the Say's Phoebe is presently a rare breeder in extreme southwestern and south-central sections of Manitoba. Its status in the remainder of southwestern Manitoba is uncertain. Godfrey included east-central Saskatchewan in the breeding range of the Say's Phoebe, therefore the species may nest as far north as west-central Manitoba. ${ }^{1}$ 
Suitable habitat, primarily abandoned farmsteads with nearby mixed-grass prairie or pastures, throughout southwestern, south-central and west-central Manitoba should be checked for this species.

1 GODFREY, W.E. 1986. The birds of Canada, revised edition. Nat. Museum of Natural Sciences, Ottawa. 595 pp.

2 KNAPTON, R.W. 1977. Breeding status of the
Say's Phoebe in Manitoba. Blue Jay 91:183.

3 KNAPTON, R.W. 1979. Birds of the Gainsborough-Lyleton Region. Sask. Nat. Hist. Society, Spec. Pub. No. 10. 72 pp.

${ }^{4}$ LAWRENCE, A.G. 1934. Chickadee notes \#588, 1 June 1934. Winnipeg Free Press, Winnipeg, Manitoba.

5 TAVERNER, P.A. 1927. Some recent Canadian records. Auk 44:217-228.

\section{CALL FOR ASSISTANCE: BIRD DONATIONS TO THE SASKATCHEWAN MUSEUM OF NATURAL HISTORY}

As the new Curator of Ornithology at the Saskatchewan Museum of Natural History in Regina, I would like to outline the museum's present position regarding bird donations. In the past many people have played a role in building and maintaining the museum's bird collections and displays by sending specimens of birds found dead. We currently need donations of all species of birds found dead that are in good condition. One problem that we sometimes encounter is a lack of documentation with the specimens that we receive. The following information is required with specimens to make them of value for scientific study:

1) date of collection

2) location of collection

3) name, address and telephone number of collector

Prior to freezing, place the specimen in a plastic bag to prevent dehydration and include the information inside the bag with the bird. I look forward to your continued input; the value of these donations to the museum's collection cannot be overemphasized. Thank-you. - Paul C. James, Saskatchewan Museum of Natural History, Wascana Park, Regina, Saskatchewan. S4P 3V7 